Invited Review

\title{
COVID-19 and animals: What do we know?
}

\author{
Serkan Gönültaş ${ }^{1}$ (D), Murat Karabağlı² (D), Yavuz Baştuğ ${ }^{3}$ (D), Nusret Can Çilesiz ${ }^{4}$, Ateş Kadıoğlu5 (i) \\ Cite this article as: Gönültaş S, Karabağlı M, Baştuğ Y, Çilesiz NC, Kadığlu A. COVID-19 and animals: What do we know? Turk J Urol \\ 2020; 46(4): 249-52.
}

ORCID iDs of the authors:

S.G. 0000-0001-6556-7751;

M.K. 0000-0002-3936-1730;

Y.B. 0000-0002-9256-940X;

N.C.C. 0000-0003-2115-698X

A.K. 0000-0002-4239-7638.

${ }^{1}$ Department of Urology, Gaziosmanpaşa Training and

Research Hospital, İstanbul,

Turkey

${ }^{2}$ Department of Surgery,

İstanbul University-

Cerrahpaşa, Faculty of

Veterinary, İstanbul, Turkey

${ }^{3}$ Department of Urology,

Haydarpaşa Training and

Research Hospital, İstanbul,

Turkey

${ }^{4}$ Department of Urology,

Florence Nightingale Hospital,

İstanbul, Turkey

${ }^{5}$ Department of Urology,

İstanbul, University, İstanbul

School of Medicine, İstanbul,

Turkey

Submitted:

08.05.2020

Accepted:

14.05.2020

Available Online Date:

15.05.2020

Corresponding Author:

Serkan Gönültaş

E-mail:

dr.serkangonultas@hotmail.com

(C) Copyright 2020 by Turkish

Association of Urology

Available online at

www.turkishjournalofurology.com

\begin{abstract}
Coronaviruses, which were generally considered harmless to humans before 2003, have appeared again with a pandemic threatening the world since December 2019 after the epidemics of SARS and MERS. It is known that transmission from person to person is the most important way to spread. However, due to the widespread host diversity, a detailed examination of the role of animals in this pandemic is essential to effectively fight against the outbreak. Although coronavirus infections in pets are known to be predominantly related to the gastrointestinal tract, it has been observed that there are human-to-animal transmissions in this outbreak and some animals have similar symptoms to humans. Although animal-to-animal transmission has been shown to be possible, there is no evidence of animal-to-human transmission.
\end{abstract}

Keywords: Animal; coronavirus; Covid-19; human; transmission.

\section{Introduction}

Coronaviruses are included in the subfamily $O r$ thocoronavirinae of the family Coronaviridae. The Orthocoronovirinaea subfamily is classified into four genera (Alpha-, Beta-, Gamma-, and Delta-coronaviruses) and a number of subgenera below these genera. ${ }^{[1-3]}$ Coronaviruses are enveloped ribonucleic acid (RNA) viruses with a single chain and they do not contain RNA-dependent RNA polymerase enzymes but encode these enzymes in their genomes. They have rodlike extensions on their surfaces. ${ }^{[1,4]}$ Due to receptor protrusions, high frequency of mutations, and RNA instabilities, they exhibit a wide host range and can be found in humans, bats, pigs, cats, dogs, rodents, and poultry. ${ }^{[1,5,6]}$

The first human coronavirus $(\mathrm{HCoV})$ strain (HCoV-229E) was isolated from the nasal discharge of patients with a cold in the mid-1960s. [7] The strains of HCoV-229E and subsequent HCoV-OC43 have caused self-limiting, simple respiratory diseases ${ }^{[8]}$ Before 2003, it was widely accepted that coronavirus infections were generally harmless to humans. In 2003, SARS-CoV was registered as the cause of the first serious coronavirus outbreak with more than 8,000 people infected and a mortality rate of approximately
$10 \% .^{[9,10]}$ Ten years later, the Middle East respiratory syndrome (MERS) outbreak resulted in a permanent epidemic in the Arabian Peninsula and spread sporadically to the rest of the world. ${ }^{[11-}$

${ }^{13]}$ Finally, the coronavirus disease (COVID-19) pandemic, caused by a novel coronavirus named SARS-CoV-2, broke out in China in December 2019, and it has been detected in more than 3,000,000 people till May 2020 and has caused more than 200,000 deaths. ${ }^{[14]}$

It is known that person-to-person transmission is the most important method of virus spread. However, to effectively fight this pandemic, which is considered a zoonotic disease, a detailed examination of the role of animals is essential.

\section{COVID-19 disease in animals}

Before the occurrence of the first highly pathogenic $\mathrm{HCoV}$, SARS-CoV, there was little information about $\mathrm{HCoVs}$, whereas extensive information about animal corona viruses, their evolution, and pathobiology is available. It is known that tissue tropisms and virulence evolve very quickly; they cause severe infectious diarrhea in dogs (canine coronavirus), pigs (porcine respiratory coronavirus and swine acute diarrhea syndrome coronavirus), and bats (porcine epidemic diarrhea virus and 
transmissible gastroenteritis virus), and infectious bronchitis attacks in some feline and poultry animals (infectious bronchitis virus and feline infectious peritonitis virus), and many medications are used for their treatment. ${ }^{[15-18]}$

Although, in terms of genome sequencing, SARS-CoV-2 showed $96.2 \%$ identity with the coronavirus (RaTG13) detected in horseshoe bats (Rhinolophus spp.) in Yunnan province in 2013 , it was not previously observed in animals. As the first case in animals, a positive test result was reported in a Pomeranian dog on February 28, 2020, by the Hong Kong Agriculture, Fisheries and Conservation Department. ${ }^{[19]}$ Subsequently, positive test results were reported in two dogs, two domestic cats, four tigers, and three lions. ${ }^{[20-22]}$ Although dogs were asymptomatic, a domestic cat was found to have symptoms such as vomiting, diarrhea, and difficulty in breathing, and the tigers and lions had dry cough and wheezing.

In a study evaluating animals having close contact with people, it was shown that farm animals, including pigs, chickens, and ducks, were not susceptible to the virus. Dogs were poorly susceptible, but ferrets and especially young cats were very sensitive to SARS-CoV-2. ${ }^{[23]}$ When macaques from non-human primates were examined, SARS-CoV-2 was shown to produce clinical and radiological findings similar to the picture in humans, especially in the elderly. ${ }^{[24,25]}$

In animal autopsies, appearances only involving the upper respiratory tract were observed in ferrets, but serious lesions were found in the nasal and tracheal mucosal epithelium and lungs in cats. Although viral RNA was observed in the intestinal organs, no significant histological changes were observed. It was observed that viral RNA was positive until the 11th day in the washing samples taken from the noses and soft palates of the cats and ferrets and in the feces of the cats, and until the 6th day in the dogs. ${ }^{[23]}$

\section{COVID-19: Transmission from human to animal}

Before the pandemic, SARS-CoV-2 was not observed in animals. The fact that the owner of the Pomeranian dog, which

\section{Main Points:}

- The role of animals in the spread of SARS-CoV-2 is examined in detail herein.

- Occurrence of human-to-animal and animal-to-animal transmissions have been demonstrated.

- Animal-to-human transmission has not been reported thus far.

- Quarantining pets at home has been recommended.

- It is recommended that health strategies be restructured to include animals. was reported as the first positive animal case, was found to be positive before raised the issue of human-to-animal transmission. ${ }^{[19]}$ Subsequently, the tests of the owners of four dogs that were tested and a domestic cat with diarrhea and respiratory symptoms and positive test result were also positive. ${ }^{[20,26]}$ The positive test result of the caretaker of the tigers, which were found positive in the zoo, strengthened the view that there was transmission from humans to animals. ${ }^{[27]}$ Because such data have been increasing day by day, the World Organization of Animal Health has suggested that human-to-animal transmission may occur, and therefore, COVID-19 patients should limit contact with pets and other animals until more information about the virus is known. ${ }^{[28]}$ All these suggest that the real effect of the disease can be felt for months beyond disease control. ${ }^{[29]}$

\section{COVID-19: Transmission from animal to animal}

It is known that SARS-CoV, the first serious coronavirus epidemic agent, can infect domestic cats, although data on dogs cannot be found, and transmission among them can occur even if symptoms do not develop. ${ }^{[30]}$ Understanding the transmission potential of the SARS-CoV-2 virus from animal to animal due to its genome sequences and receptor properties similar to SARS$\mathrm{CoV}$ is very important for effective strategies against the pandemic. ${ }^{[31]}$ Preliminary studies showed that SARS-CoV-2 spread from cat to cat, and that specific neutralizing antibodies against this type of SARS-CoV-2 were produced. ${ }^{[23,32]}$ In another study, viral RNA was found to be positive in all ferrets in the same cage with the virus incubated ferrets and in a few ferrets in the adjacent cage. Thus, it has been shown that animal-to-animal transmission by airway as well as by direct contact can occur. ${ }^{[33]}$ This information raises the concern that there may be an increase in the number of people leaving their pets. Computer simulations have been performed to estimate how this may affect outbreakrelated outcomes, and it has been anticipated that the number of animals to be abandoned may reveal significant differences in the risk of transmission. ${ }^{[34]}$ It has been argued that quarantining animals at home would be a better strategy to control the spread of the virus. ${ }^{[35]}$

\section{COVID-19: Transmission from animal to human}

SARS-CoV-2 is considered to have been first transmitted from bats as the genome sequence was $96.2 \%$ identical to the coronavirus RaTG13 detected in horseshoe bats (Rhinolophus spp.) in Yunnan province in 2013. However, it is not yet known whether it was transmitted from bats to humans directly, or whether there was an intermediate host in the transmission. ${ }^{[36-39]}$ In addition, there is no evidence yet to show that there is reverse zoonosis from animals to humans, which will cause the epidemic to become panzoonotic. ${ }^{[40]}$ However, this potential public health concern requires further research. 


\section{Conclusion}

It is known that transmission from person to person is the main route of spread in the SARS-CoV-2 pandemic. It is recommended that people who are sick should limit their contact with pets and other animals, and quarantine their pets at home, owing to the demonstration of human-to-animal and animal-to-animal transmissions. Animal-to-human transmission has not yet been demonstrated, but given the potential public health concern, health strategies need to be restructured comprehensively, not only during this outbreak but also in potential future outbreaks.

Peer-review: This manuscript was prepared by the invitation of the Editorial Board and its scientific evaluation was carried out by the Editorial Board.

Author Contributions: Concept - A.K.; Design - S.G.; Supervision A.K.; Data Collection and/or Processing - S.G.; Analysis and/or Interpretation - S.G.; Literature Search - M.K., Y.B., N.C.Ç.; Writing Manuscript - S.G.; Critical Review - A.K.

Conflict of Interest: The authors have no conflicts of interest to declare.

Financial Disclosure: The authors declared that this study has received no financial support.

\section{References}

1. Su S, Wong G, Shi W, Liu J, Lai ACK, Zhou J, et al. Epidemiology, Genetic Recombination, and Pathogenesis of Coronaviruses. Trends Microbiol 2016;24:490-502. [Crossref]

2. Wong LY, Lui PY, Jin DY. A molecular arms race between host innate antiviral response and emerging human coronaviruses. Virol Sin 2016;31:12-23. [Crossref]

3. Chan JF, Kok KH, Zhu Z, Chu H, To KK, Yuan S, et al. Genomic characterization of the 2019 novel human-pathogenic coronavirus isolated from a patient with atypical pneumonia after visiting $\mathrm{Wu}-$ han. Emerg Microbes Infect 2020;9:221-36. [Crossref]

4. Weiss SR, Navas-Martin S. Coronavirus pathogenesis and the emerging pathogen severe acute respiratory syndrome coronavirus. Microbiol Mol Biol Rev 2005;69:635-64. [Crossref]

5. Li X, Song Y, Wong G, Cui J. Bat origin of a new human coronavirus: there and back again. Sci China Life Sci 2020;63:461-2. [Crossref]

6. Su S, Wong G, Shi W, Liu J, Lai ACK, Zhou J, et al. Epidemiology, genetic recombination, and pathogenesis of coronaviruses. Trends Microbiol 2016;24:490-502. [Crossref]

7. Kendall EJ, Bynoe ML, Tyrrell DA. Virus isolations from common colds occurring in a residential school. Br Med J 1962;2:82-6. [Crossref]

8. New respiratory virus. Br Med J 1967;3:752. [Crossref]

9. Cheng VC, Lau SK, Woo PC, Yuen KY. Severe acute respiratory syndrome coronavirus as an agent of emerging and reemerging infection. Clin Microbiol Rev 2007;20:660-94. [Crossref]
10. Peiris JS, Lai ST, Poon LL, Guan Y, Yam LY, Lim W, et al. Coronavirus as a possible cause of severe acute respiratory syndrome. Lancet 2003;361:1319-25. [Crossref]

11. Zaki AM, van Boheemen S, Bestebroer TM, Osterhaus AD, Fouchier RA. Isolation of a novel coronavirus from a man with pneumonia in Saudi Arabia. N Engl J Med 2012;367:1814-20. [Crossref]

12. Hilgenfeld R, Peiris M. From SARS to MERS: 10 years of research on highly pathogenic human coronaviruses. Antiviral Res 2013;100:286-95. [Crossref]

13. Gao H, Yao H, Yang S, Li L. From SARS to MERS: evidence and speculation. Front Med 2016;10:377-82. [Crossref]

14. WHO Coronavirus disease (COVID-2019) situation reports-102. Available from: https://www.who.int/emergencies/diseases/novelcoronavirus-2019

15. Decaro N, Lorusso A. Novel human coronavirus (SARSCoV-2): a lesson from animal coronaviruses. Vet Microbiol 2020;244:108693. [Crossref]

16. Decaro N, Mari V, Campolo M, Lorusso A, Camero M, Elia G, et al. Recombinant canine coronaviruses related to transmissible gastroenteritis virus of swine are circulating in dogs. J Virol 2009;83:1532-7. [Crossref]

17. Lorusso A, Decaro N, Schellen P, Rottier PJ, Buonavoglia C, Haijema BJ, et al. Gain, preservation, and loss of a group 1a coronavirus accessory glycoprotein. J Virol 2008;82:10312-7. [Crossref]

18. Addie DD, Curran S, Bellini F, Crowe B, Sheehan E, Ukrainchuk L, et al. Oral Mutian ${ }^{\circledR}$ X stopped faecal feline coronavirus shedding by naturally infected cats. Res Vet Sci 2020;130:222-9. [Crossref]

19. AFCD. Detection of low level of COVID-19 virus in pet dog. Available from: www.afcd.gov.hk/english/publications/publications_press/pr2335.html (accessed 24 March 2020)

20. The Government of the Hong Kong Special Administrative Region - Press Releases. 2020a. Pet dog tests positive for COVID-19 virus. [cited 2020 Apr 1]. Available from: https://www.info.gov.hk/ gia/general/202003/19/P2020031900606.htm

21. The Government of the Hong Kong Special Administrative Region - Press Releases. 2020b. Pet dog further tests positive for antibodies for COVID-19 virus. [cited 2020 Apr 1]. Available from: https:// www.info.gov.hk/gia/general/202003/26/P2020032600756.htm

22. The Government of the Hong Kong Special Administrative Region - Press Releases. 2020c. Pet cat tests positive for COVID-19. [cited $2020 \mathrm{Feb} 4$ ]. Available from: https://www.info.gov.hk/gia/ general/202003/31/P2020033100717.htm

23. Shi J, Wen Z, Zhong G, Yang H, Wang C, Huang B, et al. Susceptibility of ferrets, cats, dogs, and different domesticated animals to SARS coronavirus 2. Science 2020; DOI: 10.1126/science. abb7015. [Crossref]

24. Rockx B, Kuiken T, Herfst S, Bestebroer T, Lamers MM, Oude Munnink BB, et al. Comparative pathogenesis of COVID-19, MERS, and SARS in a nonhuman primate model. Science 2020; DOI: $10.1126 /$ science.abb7314. [Crossref]

25. Yu P, Qi F, Xu Y, Li F, Liu P, Liu J, et al. Age-related rhesus macaque models of COVID-19. Animal Model Exp Med 2020;3:937. [Crossref]

26. The Brussels Times. Coronavirus: Belgian woman infected her cat. Available from: https://www.brusselstimes.com/all-news/ belgium-allnews/103003/coronavirus-belgian-woman-infectedher-cat/ 
27. USDA Statement on the Confirmation of COVID-19 in a Tiger in New York. Available from: https://www.aphis.usda.gov/aphis/ newsroom/news/sa_by_date/sa-2020/ny-zoo-covid-19

28. World Organisation for Animal Health (WOAH): Questions and Answers on the 2019 Coronavirus Disease (CO VID- 19). Available from: https://www.oie.int/en/scientific-expertise/specificinformation-and-recommendations/questions-and-answers-on2019novel-coronavirus/. Accessed March 9, 2020.

29. Ho HC, Hughes T, Bozlu M, Kadığlu A, Somani BK. What do urologists need to know: Diagnosis, treatment, and followup during COVID-19 pandemic. Turk J Urol 2020;46:169-77. [Crossref]

30. Martina BE, Haagmans BL, Kuiken T, Fouchier RAM, Rimmelzwaan GF, Van Amerongen G, et al. Virology: SAR S virus infection of cats and ferrets. Nature 2003;425:915. [Crossref]

31. Lu R, Zhao X, Li J, Niu P, Yang B, Wu H, et al. Genomic characterisation and epidemiology of 2019 novel coronavirus: implications for virus origins and receptor binding. Lancet 2020;395:565-74. [Crossref]

32. Zhang Q, Zhang H, Huang K, Yang Y, Hui X, Gao J, et al. SARS CoV 2 neutralizing serum antibodies in cats: a serological investigation [Internet]. Wuhan, 2020. Available from: https://www. biorxiv.org/content/10.1101/2020.04.01.021196v1 [Crossref]
33. Kim YI, Kim SG, Kim SM, Kim EH, Park SJ, Yu KM, et al. Infection and Rapid Transmission of SARS-CoV-2 in Ferrets. Cell Host Microbe 2020; DOI: 10.1016/j.chom.2020.03.023. [Crossref]

34. Gao T, Pan X, Pan C. The fate of house cats during the COVID-19 pandemic. Microbes Infect 2020; pii: S1286-4579(20)30073-3. [Crossref]

35. Science News: Available from: https://www.sciencemag.org/ news/2020/03/quarantine-cat-disinfect-dog-latest-advice-aboutcoronavirus-and-your-pets

36. Zhou P, Yang XL, Wang XG, Hu B, Zhang L, Zhang W, et al. A pneumonia outbreak associated with a new coronavirus of probable bat origin. Nature 2020;579:270-3.

37. Cyranoski D. Mystery deepens over animal source of coronavirus. Nature 2020;579:18-9. [Crossref]

38. Singhal T. A Review of Coronavirus Disease-2019 (CO VID- 19). Indian J Pediatr 2020;87:281-6. [Crossref]

39. Guo YR, Cao QD, Hong ZS, Tan YY, Chen SD, Jin HJ, et al. The origin, transmission and clinical therapies on coronavirus disease 2019 (CO VID- 19) outbreak - an update on the status. Mil Med Res 2020;7:11. [Crossref]

40. First case human-to-dog transmission in Hong Kong. Available from: https://www.livescience.com/coronavirus-first-case-humanto-dog-transmission.html. 